\title{
Hydrophyte-macroinvertebrate interactions in Zwemlust, a lake undergoing biomanipulation
}

\author{
Ryszard Kornijów, Ramesh D. Gulati' \& Ellen van Donk ${ }^{2}$ \\ Department of Zoology and Hydrobiology, Agricultural Academy, Akademicka 13, 20-934 Lublin, \\ Poland; ' Correspondence address: Limnological Institute, 'Vijverhof' Laboratory, Rijksstraatweg 6, 3631 \\ AC Nieuwersluis, The Netherlands; ${ }^{2}$ Provincial Waterboard of Utrecht, Postbox 80300, 3508 TH Utrecht, \\ The Netherlands
}

Key words: macrozoobenthos, macrophytofauna, macrophytes, macroalgae, biomanipulation, trophic relations

\begin{abstract}
In two years after biomanipulation of Lake Zwemlust (The Netherlands), macrophytes (helophytes, elodeids) and filamentous algae developed luxuriantly in the lake. They influenced the structure of macroinvertebrate communities inhabiting them. Macrophytes and algae, by changing environmental and trophic conditions, also affected the composition of macrozoobenthos. Vascular plants served as an important source of food for zoobenthos and phytofauna, mainly after they were decomposed. Filamentous algae were consumed readily alive by many animals. Invertebrates appeared to be important as a potential nutrient source for hydrophytes.
\end{abstract}

\section{Introduction}

The main goal of biomanipulation, i.e. a decrease of phytoplankton density and an increase of water transparency, can often lead to the luxuriant growth of macrophytes, or filamentous algae or both (e.g. Gulati \& Van Donk, 1989; Meijer et al., 1989; Van Donk et al., 1989). The role of macrophytes in stabilizing a lake ecosystem, especially by the uptake of nutrients, allelopathy and offering a shelter to zooplankton and piscivorous fish, has been stressed by many workers (Moss et al., 1988; Gulati, 1989; Grimm, 1989; Van Donk et al., 1989). But macrophytes and filamentous algae also create a new habitat for the periphytic fauna as well as change the environmental and trophic conditions for fauna inhabiting the bottom sediments. On the other hand, the phytofauna affects the light conditions for plants by grazing on periphytic organisms and, together with zoobenthos, contributed to the nutrient cycling by transformation of organic matter. So far, these problems have not been considered in the studies dealing with food-web manipulation.

The aim of the present paper is to study these relationships as well as the role of the macrofauna in the functioning of the small Lake Zwemlust undergoing biomanipulation since 1987 . The investigations formed a part of the studies on different ecological aspects in relation to influence of biomanipulation on lakes ecosystem (Gulati, 1989; Van Donk et al., 1989). 


\section{The lake and biomanipulation measures}

Lake Zwemlust is a hypertrophic, small (1.5 ha) and shallow (mean depth $1.5 \mathrm{~m}$; max. depth $2.5 \mathrm{~m}$ ) reservoir (Fig. 1). It is located in the Province of Utrecht, The Netherlands. The lake is used as a swimming pool in summer. It receives underground seepage water from the polluted River Vecht running about $50 \mathrm{~m}$ west of the lake. Because of high concentration of nutrients, both $\mathrm{N}$ and $\mathrm{P}$, in the seepage water from the river, environmental conditions in the lake deteriorated in the last two decades or so. Cyanobacterial blooms (e.g. Microcystis) became recurrent and vascular submerged plants disappeared. For improving the water quality several unsuccessful attempts were made in the past but biomanipulation was tried first in March, 1987 (Gulati, 1989; Van Donk et al.. 1989).

The biomanipulation measures involved removing the planktivore bream (Abramis brama) and introducing pike (Esox lucius) and as its prey rudd (Scardinius erytrophthalmus). Also 'seedlings' of Chara globularis and roots of Nuphar lutea were introduced (for details see Van Donk

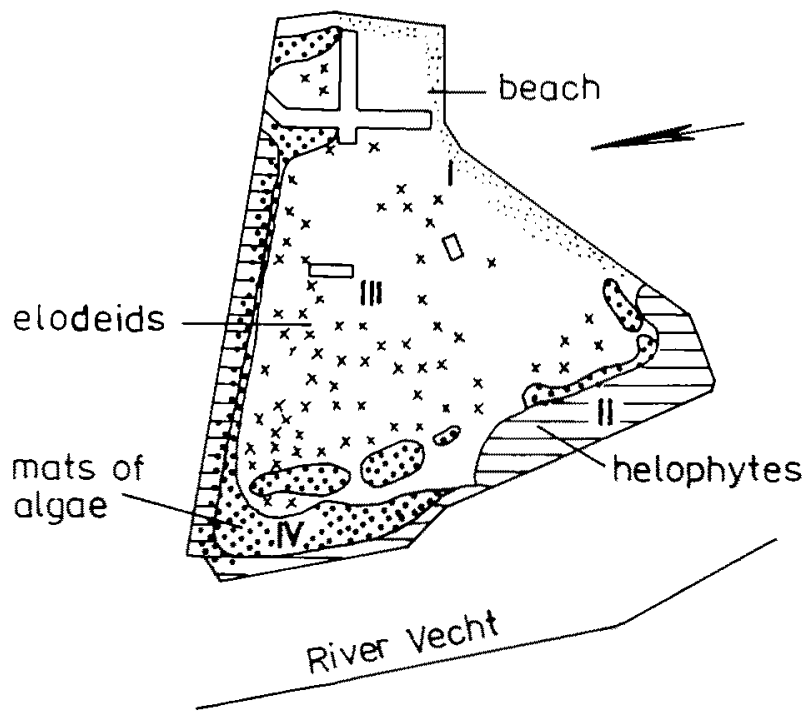

Fig. 1. Schematic map of Lake Zwemlust with sampling stations I-IV and distribution of plants (from Van Donk et al., 1989, with some modifications). et al., 1989). As a result of increased grazing by herbivore zooplankton (Gulati, 1989), abundance of phytoplankton decreased, leading to a marked increase in Secchi-disc depth which extended to the lake's bottom (Van Donk et al., 1989). Moreover, the macrophytes and filamentous algae developed luxuriantly during summer of 1988 (Ozimek et al., 1990). During the study period in 1988, helophytes were dominated by Phragmites australis and submerged plants primarily by Elodea nuttallii, Ceratophyllum demersum and Chara globularis. Besides, the surface of western and northern parts of the lake were covered by floating mats of filamentous algae, mainly Mougeotia sp. and Hydrodictyon sp. (Ozimek et al., 1990).

\section{Methods}

The macrofauna living in the three general habitat types, i.e. on dominant macrophytes, mats of filamentous algae and in bottom sediments overgrown by them, was analysed. Sampling was done monthly from September to December, 1988, at four locations (Fig. 1), which differed with regards to the depth, physical parameters, type of bottom deposits and vegetations (Table 1). At each location and habitat type three or four replicate samples were collected. The bottom material was taken with a corer-type sampler, with a trapping surface of $20 \mathrm{~cm}^{2}$ and sieved through at net of $0.3 \mathrm{~mm}$ mesh size. Macrofauna associated with different macrophytes was sampled using different sampling techniques. A grab was used in case of E. nuttallii, $C$. demersum and C. globularis, a pair of secateurs for $P$. australis. Filamentous algae were collected by hand. Each sample contained 20 stems of reed and about $50 \mathrm{~g}$ wet weight of the remaining plants. Live animals were removed both from the plants and macrozoobenthos macroscopically and preserved with $4 \%$ formalin.

The density and biomass of both phytomacrofauna and macrozoobenthos were measured and expressed as ind $\mathrm{m}^{-2}$ and their wet weight $\mathrm{m}^{-2}$ of the lake bottom, respectively. Information on the biomass of plants was obtained 
Table 1. Physical characteristics of sites (I-IV) in Lake Zwemlust in October, 1988: S, near Surface, B, near Bottom.

\begin{tabular}{|c|c|c|c|c|c|c|c|c|}
\hline \multirow[t]{2}{*}{ Parameters } & \multicolumn{2}{|l|}{ I } & \multicolumn{2}{|l|}{ II } & \multicolumn{2}{|l|}{ III } & \multicolumn{2}{|l|}{ IV } \\
\hline & $S$ & B & $\mathrm{S}$ & B & $\mathrm{S}$ & B & $\mathbf{S}$ & B \\
\hline Conductivity $\left(\mu \mathrm{S} \mathrm{cm}^{-1}\right)$ & 304 & 304 & 323 & 323 & 304 & 304 & 470 & 319 \\
\hline Light $\left(\mu \operatorname{Ein} \mathrm{m}^{-2}\right)$ & 1500 & 1300 & - & - & 1200 & 100 & 1200 & 0.2 \\
\hline Oxygen ( $\left.\mathrm{mg} \mathrm{O}_{2} \mathrm{l}^{-1}\right)$ & 10.4 & 10.4 & 9.0 & 9.0 & 10.4 & 10.4 & 10.4 & 6.0 \\
\hline Temperature $\left({ }^{\circ} \mathrm{C}\right)$ & 11.2 & 11.2 & 11.8 & 11.8 & 11.2 & 11.0 & 12.2 & 11.0 \\
\hline Bottom deposits & \multicolumn{2}{|c|}{$\begin{array}{l}\text { Sand with some } \\
\text { fine detritus }\end{array}$} & \multicolumn{2}{|c|}{$\begin{array}{l}\text { Ca. } 10 \mathrm{~cm} \text { thick } \\
\text { detritus layer } \\
\text { fragments of } \\
\text { Phragmites }\end{array}$} & \multicolumn{2}{|c|}{$\begin{array}{l}\mathrm{Ca} .2 \mathrm{~cm} \text { well de- } \\
\text { composed detritus } \\
\text { covering sand, peat } \\
\text { or clay }\end{array}$} & \multicolumn{2}{|c|}{ Like at site III } \\
\hline Vegetation & \multicolumn{2}{|l|}{ None } & \multicolumn{2}{|c|}{$\begin{array}{l}\text { Dense belt of } \\
\text { Phragmites }\end{array}$} & \multicolumn{2}{|c|}{$\begin{array}{l}\text { Clusters of Elodea. } \\
\text { Chara and beds of } \\
\text { Ceratophyllum }\end{array}$} & \multicolumn{2}{|c|}{$\begin{array}{l}\text { Algal mats (mainly } \\
\text { Mougeotia and } \\
\text { Hydrodictyon) }\end{array}$} \\
\hline
\end{tabular}

from Ozimek et al. (1990). Also the coefficient $(Q)$ of ecological significance of species was calculated, according to the formula of Kasprzak \& Niedbala (1981):

$$
Q=\sqrt{C \cdot D}
$$

where $C$ is constancy of occurrence (frequency) and $D$ is coefficient of dominance.

Since the communities inhabiting the three dominant submerged plant species did not greatly differ, they have been treated together as fauna of elodeids.

\section{Results and discussion}

Habitat relationships: Of the 76 taxa of macroinvertebrates found 63 occurred in the bottom sediments ( 26 exclusively); 63 taxa belonged to the fauna living on water plants (17 exclusively). The direct effect of vascular plants and macroalgae as a substrate for the phytomacrofauna inhabiting them concerned mainly its quantitative structure, like observed by other workers (Krecker, 1939; Higler, 1977; Dvorak \& Best, 1982; Rooke, 1984; Kornijow, submitted). Relative proportions of the main taxonomic groups of animals are illustrated in Fig. 2. The most numerous invertebrates on the helophytes were gastropods, on elodeids, chironomids, larvae and gastropods. In mats of algae, larvae of chironomids, heleids and trichopterans (Agraylea multipunctata) were abundant. Those having significant share in biomass were: gastropods on helophytes, gastropods and trichopterans on elodeids, and tipulids and gastropods and mats of algae.

The relationships between morphological structure of the plants and the occurrence of separate animals were clear only in a few cases. For example, the snail Acroloxus lacustris occurred exclusively on reed, where its $Q$ coefficient was higher (Table 2). It is known that the broad and smooth surface of reed facilitates locomotion and, to some extent, also feeding of the snail.

The indirect influence of macrophytes and macroalgae on animal communities in bottom sediments consisted mainly of changing the physical properties of bottom sediments and the water, especially the latter's light conditions and oxygen concentration (Table 1). In the presence of dense stands of vegetation, especially of emerged macrophytes, the amount of detritus in the bottom deposits was substantial (except at site I) and thus the bottom fauna was represented mainly by pelo- 


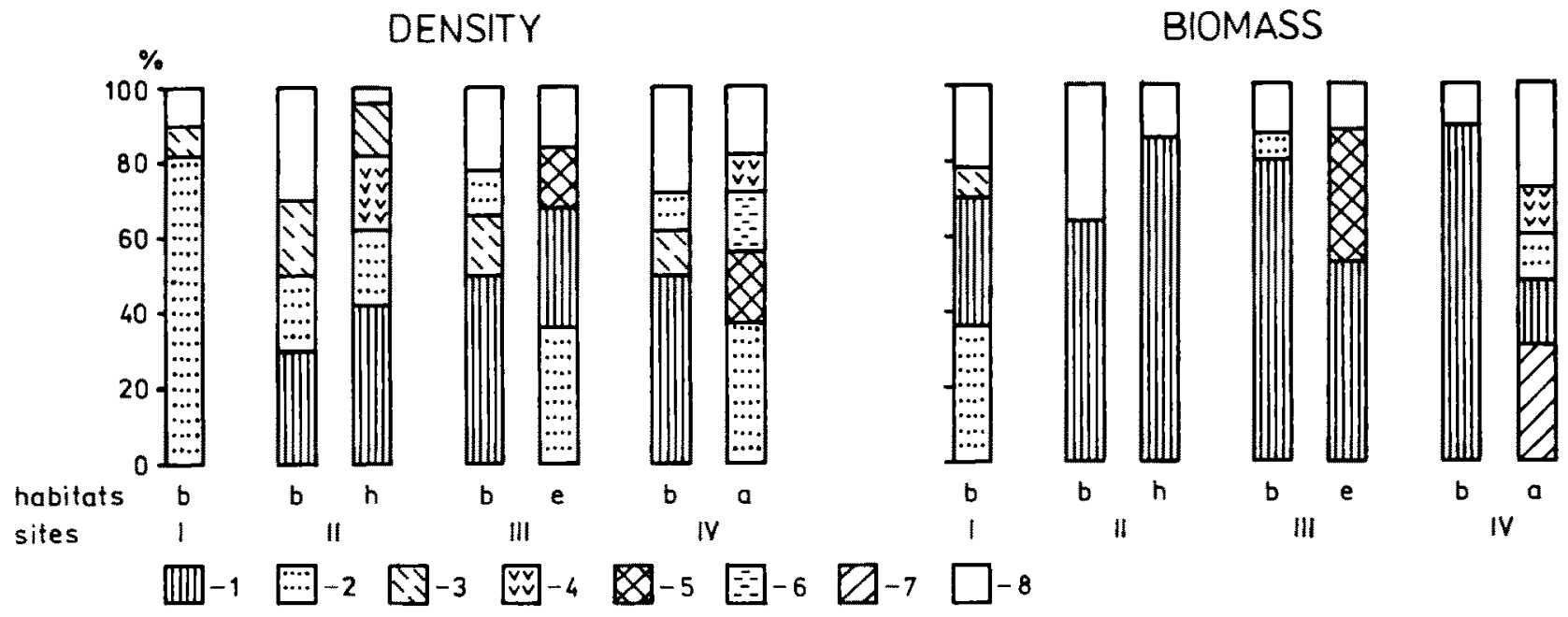

Fig. 2. Average percentage of the most important groups in the density and biomass of the zoobenthos (b) and phytofauna inhabiting helophytes (h), elodeids (e) and mats of algae (a): 1, Gastropoda; 2, Chironomidae; 3, Tubificidae; 4, Hirudinea; 5. Trichoptera: 6, Heleidae; 7, Tipulidae; 8 , others.

Table 2. Macrofauna in Lake $Z$ wemlust having $Q$ values (ecological significance coefficient) of $>15$, at least at one of the four sites (I-IV), and habitats; B-bottom sediments; $\mathrm{H}$-helophytes; E-elodeids; A-algae.

\begin{tabular}{|c|c|c|c|c|c|c|c|}
\hline \multirow[t]{2}{*}{ Taxa } & \multirow{2}{*}{$\frac{\mathrm{I}}{\mathrm{B}}$} & \multicolumn{2}{|l|}{ II } & \multicolumn{2}{|l|}{ III } & \multicolumn{2}{|l|}{ IV } \\
\hline & & B & $\mathrm{H}$ & B & E & B & A \\
\hline TUBIFICIDAE & 27.8 & 41.2 & & 31.6 & & 30.4 & \\
\hline \multicolumn{8}{|l|}{ HIRUDINEA } \\
\hline Erpobdella sp & 0.7 & 20.6 & 30.4 & 1.0 & 4.2 & & 21.5 \\
\hline \multicolumn{8}{|l|}{ GASTROPODA } \\
\hline Acroloxus lacustris (L.) & & & 25.0 & & & & \\
\hline Anisus vortex $(\mathrm{L})$. & & 19.8 & & & & & 2.9 \\
\hline Armiger crista (L.) & & & & & 19.5 & & \\
\hline Bithyia leachi Shepp. & 0.8 & 18.4 & 13.0 & 13.0 & 22.7 & 18.9 & \\
\hline Gyraulus sp. & & & & & 18.6 & & \\
\hline Planorbis planorbis (L.) & & 26.8 & & 1.6 & & 5.2 & \\
\hline Valvata piscinalis O.F. Müll. & 14.9 & 33.1 & & 65.4 & 22.6 & 58.3 & \\
\hline \multicolumn{8}{|l|}{ CRUSTACEA } \\
\hline Asellus meridianus Racov, & & 27.5 & & 3.5 & & 8.8 & \\
\hline Gammarus pulex (L.) & 15.1 & & & & & & \\
\hline \multicolumn{8}{|l|}{ TRICHOPTERA } \\
\hline Cyrnus sp. & 16.2 & 16.2 & 19.1 & 8.9 & 28.9 & 17.6 & \\
\hline Agraylea multipunctata Curt. & & & & & 25.9 & & 36.1 \\
\hline HELEIDAE & 12.3 & & 2.6 & 19.7 & 11.5 & 40.8 & \\
\hline \multicolumn{8}{|l|}{ CHAOBORIDAE } \\
\hline Chaoborus flavicans (Meig.) & & & & 9.9 & & 26.3 & \\
\hline \multicolumn{8}{|l|}{ CHIRONOMIDAE } \\
\hline Ablabesmyia sp. & & & 5.8 & & 19.5 & & 1.4 \\
\hline Acricotopus lucidus (Staeg.) & & & & & & & 37.0 \\
\hline Cricotopus gr. silvestris Fabr. & & & & & 12.9 & & 21.6 \\
\hline Cryptochironomus gr. defectus (Kief.) & 6.0 & & & & & & \\
\hline Endochironomus albipennis (Mg.) & & & 13.2 & & 21.4 & & 2.2 \\
\hline Microtendipes pedellus (Mg.) & 1.4 & 27.3 & & 3.1 & & 3.7 & \\
\hline Psectrocladius psilopterus Kieff. & & & & & 18.4 & & 1.7 \\
\hline Stictochironomus psammophilus Tshern. & 61.6 & & & & & & \\
\hline Tanytarsus gr. mancus v.d. Wulp & 63.2 & & & & & & \\
\hline
\end{tabular}


philous forms there, among with Bithynia leachi and Microtendipes pedellus were the most important (Table 2). The opposite situation occurred at site $\mathrm{I}$, where stripped macrophytes and pure inorganic particles in the bottom sediments were inhabited first of all by psammophilous larvae of Stictochironomous psammophilus and Tanytarsus gr. mancus.

The shading effect of plants, especially of algal mats, brought about significant deterioration of the light conditions (Table 1). This probably caused the larvae of Chaoborus flavicans, which avoid the sun-light (Parma, 1971), to increase in areas covered with these plants (Table 2). On the other hand photophilous larvae of Cricotopus gr. silvestris (Markosova, 1974) were very important components of the communities associated with the light-exposed plants, especially Ceratophyllum demersum and mats of algae. Another result of the shading effect of plants might be the decrease in the oxygen concentration in the water.
This decrease was noted at site IV under mats of algae (Table 1) but it possibly existed also among dense growing macrophytes during nights. Such oxygen depletions are known to retard the development of benthic animals (e.g. Slepukhina, 1986). This was, indeed, the case at sites III and IV where zoobenthos densities were the lowest (Fig. 3). These macrofaunal communities were dominated by pulmonate snails (Fig. 2), having a terrestrial mode of respiration. Gastropods as well as tubificids and larvae of Chaoborus flavicans, both of which can resist low oxygen levels, had the highest value there (Table 2). At site I, however, with sandy bottom and well oxygenated water, the bottom fauna was most numerous (Fig. 3). It was predominated by smallsized chironomid larvae (Fig. 2) (S. psammophilus and T.gr.mancus) as reflected in the lowest biomass at site I of the whole zoobenthos comparing all the sites (Fig. 3). Such an inverse relationship between the low content of organic
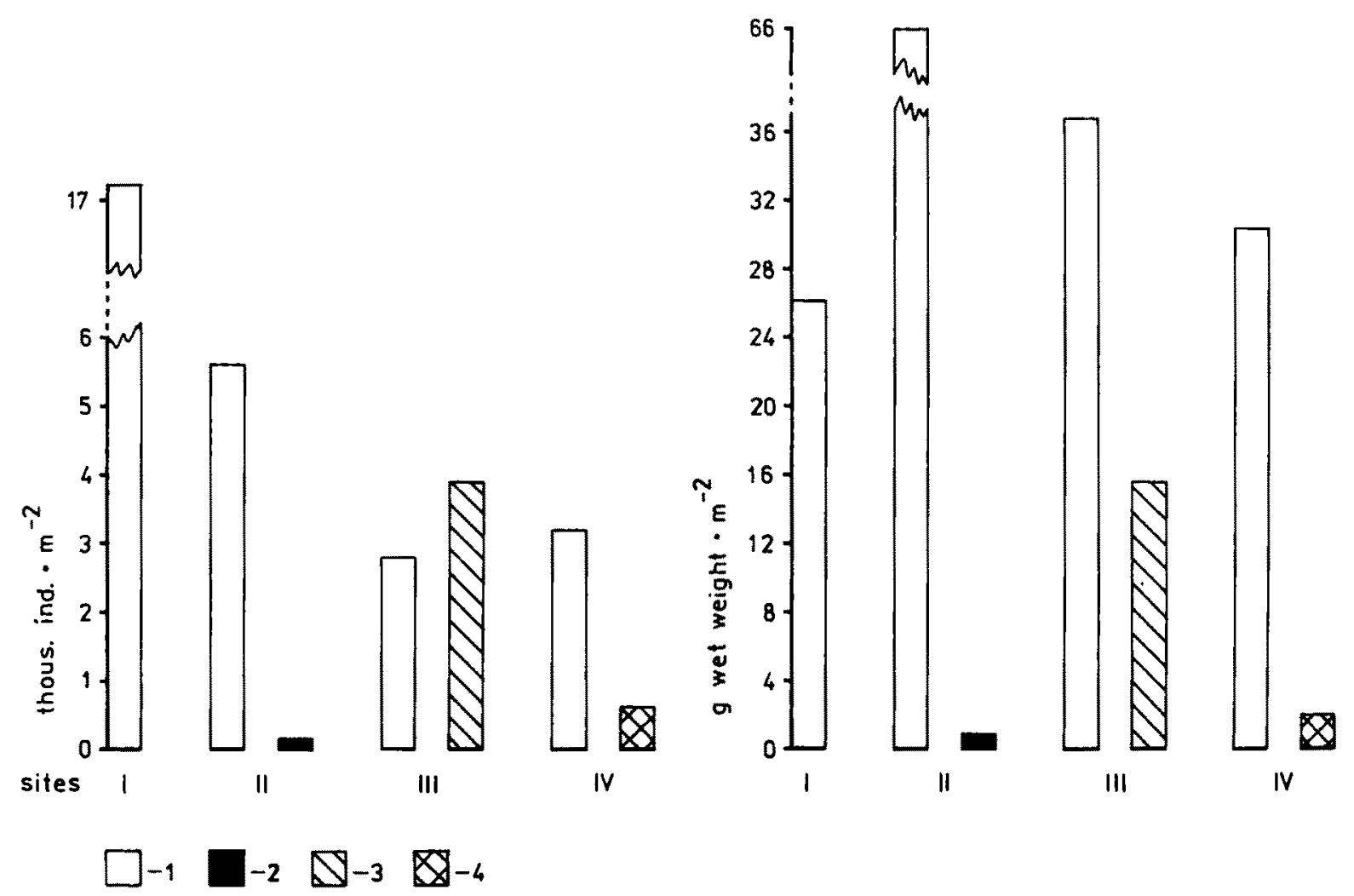

Fig. 3. Average density and biomass of the zoobenthos (1) and phytofauna inhabiting helophytes (2), elodeids (3) and mats of algae (4). 
matter, high level of oxygenation, on one hand, and small individual dimensions of benthic animals on the other has been reported also from natural, un-manipulated lakes (Kornijow, 1987).

The most unfavourable conditions appeared to be in mats of algae due to pronounced diurnal changes of oxygen concentration, temperature and $\mathrm{pH}$. It was stressed also by Hillebrand (1983) who investigated floating clusters of filamentous algae in various water bodies in The Netherlands. Variable physical conditions may cause a decrease in diversity of fauna inhabiting mats of algae, like larvae of tipulids and ephydrids, and other taxa with the highest $Q$ coefficient solely there (Table 2).

As a rule, the zoobenthos achieved both greater density and biomass than the phytofauna (Fig. 3), except the communities associated with submerged plants which were more abundant than the bottom fauna inhabiting sediments. Elodeids which occupied the majority of the bottom surface (Ozimek et al., 1990), are apparently an important habitat for the phytomacrofauna, as well as in the functioning of lakes ecosystem.

Trophic relationships: Non-predatory animals comprised 44 taxa among zoobenthos and 49 taxa among phytofauna. The constituted $38-78 \%$ and $33-76 \%$, respectively, of the biomass of these zoocoenoses. The macrophytes and filamentous algae as food source for non-predatory and omnivorous animals were important mainly after their decomposition to detritus which constituted at least $65 \%$ of their chyme volume (Fig. 4). The partly digested detritus and senescent macrophyte tissue were presumably also the main part of gut contents (indicated as undetermined greenyellow matter in Fig. 4) of non-predatory animals living on vascular plants. Green parts of these plants never exceeded $5 \%$ of the animals' food, as observed by many other workers (e.g. Otto \& Svensson, 1981).

In contrast to macrophytes, the filamentous algae, primarily Mougeotia sp. and Oedogonium
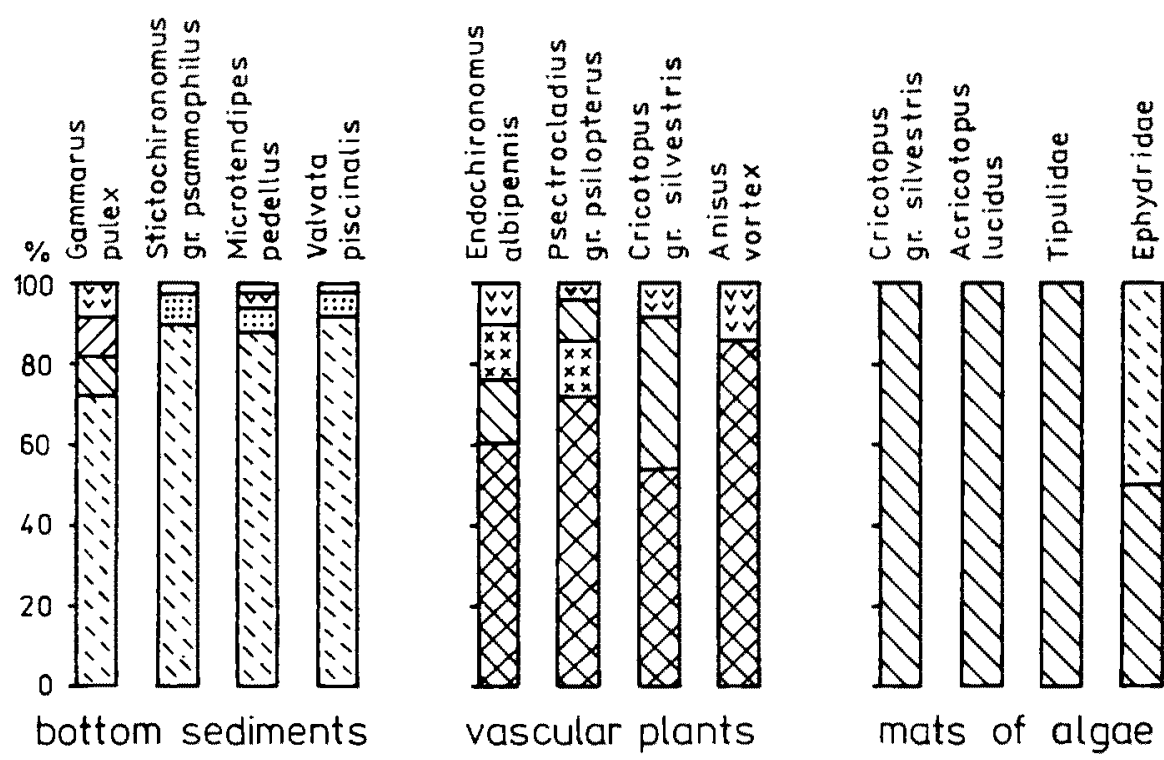

vascular plants

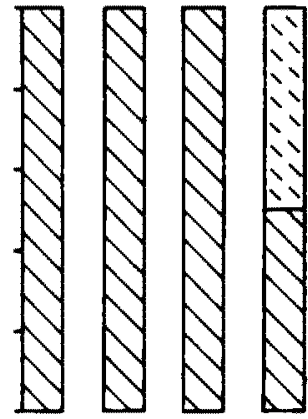

mats of algae

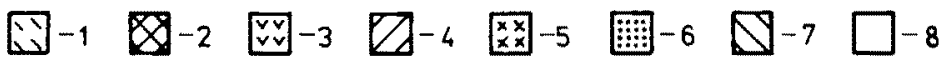

Fig. 4. Average percentage of different fractions in the food of the main representatives $(n=10-20)$ of macrofauna inhabiting bottom sediments, vascular plants and mats of algae: 1, detritus with sand; 2, un-determined green-yellow organic matter; 3, senescent macrophyte tissue; 4, animal residues; 5 , incrustations; 6, green algae (primarily Scenedesmus sp. and Pediastrum sp.) and diatoms; 7, filamentous algae (mainly Mougeotia sp. and Oedogonium sp.); 8, others. 
sp., were readily eaten live. These algae formed up to even $100 \%$ of the food of some animals inhabiting elodeids (Psectrocladius dilatatus and C. gr. silvestris) and of several invertebrates living in mats of algae (Fig. 4). Besides, during their decay in October on sedimentation, the macroalgae were the important source of food also of some benthic animals, like Lymnaea peregra, Asellus meridianus and Gammarus pulex.

The consumption of filamentous algae by some invertebrates was investigated using ${ }^{14} \mathrm{C}$ method (unpublished data). Asellus meridianus and larvae of Endochironomus albipennis were estimated to eat about $0.3 \% \mathrm{~d}^{-1}$ of the total biomass of algal mats in the lake, while the much larger snail, L. peregra $\mathrm{L}$., ca. $5 \% \mathrm{~d}^{-1}$, at the temperature of $15^{\circ} \mathrm{C}$. Together with the visual observations of the gut contents of the animals these feeding data are helpful to explain why the period of the decay of mats of algae lasted less than about one month. Literature on the importance of filamentous algae as a food source, for abundant macrofauna like in Lake Zwemlust, is scarce (Brown, 1960; Mason \& Bryant, 1975; Moore, 1975; Higler, 1977).

Presumably in the period soon after biomanipulation utilization of primary production by invertebrates in the lake occurred via grazing of abundant phytoplankton by filter-feeder and big Chironomus sp. larvae. These animals were very abundant $\left( \pm 4000\right.$ ind $\left.\mathrm{m}^{-2}\right)$ in summer of 1987 (Van Donk et al., 1989). A significant positive correlation between concentration of bio-seston in water and a development of larvae of Chironomus has been quite well demonstrated (e.g. Kajak et al., 1980). The deterioration of trophic conditions for filter-feeding chironomids, as well as a week feeding pressure of the fish on invertebrates (unpublished data of Dr. E. Lammens) might have caused an increase in the abundance of the invertebrates in Lake $Z$ wemlust. As a rule, these invertebrate predators exceeded $50 \%$ of the total biomass of the zoobenthos and the phytofauna, excluding molluscs, a situation rather seldom observed in lakes (Kajak et al., 1980; Dvorak \& Best, 1982). They probably contributed to the selective reduction in the density of the non-predatory part of both zoobenthos and phytofauna. This may explain their low densities and predominance of Gastropoda, related to luxuriant growth of macrophytes and filamentous algae both of which, together with the associated periphyton, may serve as potential food source.

Macrofauna as a store of nutrients: The average percentage $\mathrm{C}, \mathrm{N}$ and $\mathrm{P}$ in the major forms of zoobenthos and phytomacrofauna of Lake Zwemlust were $42.7,9.8$ and $0.95 \%$ respectively, on dry weight basis (Gulati \& Kornijów, unpublished). On areal basis these elements were: $1353 \mathrm{mg} \mathrm{C}, 299 \mathrm{mg} \mathrm{N}$ and $26 \mathrm{mg} \mathrm{P} \mathrm{m}^{-2}$ or $0.90 \mathrm{mg} \mathrm{C}, 0.20 \mathrm{mg} \mathrm{N}$ and $0.02 \mathrm{mg} \mathrm{P} \mathrm{I}^{-1}$ (the average depth being $1.5 \mathrm{~m}$ ). Although these concentrations form only small fractions of $\mathrm{C}, \mathrm{N}$ and $P$ bound in macrophytes and macroalgae, their role in nutrient regeneration via their feeding by macroinvertebrates may be higher than on the basis on their contents in the standing crop.

\section{Acknowledgements}

The first author acknowledges with thanks the International Agriculture Centre (Agricultural University, Wageningen) for the financial assistance for travel and stay in The Netherlands, and the Limnogical Institute, Nieuwersluis for providing laboratory facilities and free lodging.

\section{References}

Brown, D. S., 1960. The ingestion and Digestion of Algae by Cloeon dipterum L. (Ephemereptera). Hydrobiologia 15: $81-96$.

Dvorak, J. \& E. P. H. Best, 1982. Macro-invertebrate communities associated with the macrophytes of Lake Vechten: structural and functional relationships. Hydrobiologia 95: 115-126.

Grimm, M. P., 1989. Northern pike (Esox lucius L.) and aquatic vegetation, tools in the management of fisheries and water quality in shallow waters. Hydrobiol. Bull. 23: 59-65.

Gulati, R. D., 1989. Structure and feeding activities of zooplankton community in Lake Zwemlust, in the two years after biomanipulation. Hydrobiol. Bull. 23: 35-48.

Gulati, R. D. \& E. Van Donk, 1989. Biomanipulation in The 
Netherlands: applications in fresh water ecosystems and estuarine water- en introduction. Hydrobiol. Bull. $23: 1-4$.

Higler, L. W. G., 1977. Macrofauna-coenoses on Stratiotes plants in Dutch broads. Ph.D. thesis. University of Amsterdam, 86 pp.

Hillebrand, H., 1983. Development and dynamics of floating clusters of filamentous algae. In R. G. Wetzel (ed.), Periphyton of Freshwater Ecosystems. The Hague, Dr. W. Junk Publishers: 31-39.

Kairesalo, T., 1984. The Seasonal Succession of Epiphytic Communities within an Equisetum fluviatile L. Stand in Lake Pääjärvi, Southern Finland, Int, Revue ges. Hydrobiol. $69: 475-505$.

Kajak, Z., G. Bretschko, F. Schiemer \& Ch. Leveque, 1980. Zoobenthos. In E. D. LeCren \& R. H. Lowe-McConnel (eds.), The functioning of freshwater ecosystems. Cambridge University Press: 285-307.

Kasprzak, K. \& W. Niedbala, 1981. Biocenotic indicators using in quantitative analyses of the material. In M. Gorny \& L. Grüm (eds.), Statistic methods used in the soil zoology. Warsawa, PWN: 31-88.

Kornijow, R., 1988. Distribution of zoobenthos in littoral of two lakes differing in trophy. Pol. Arch. Hydrobiol. 35: 185-195.

Kornijow, R., submitted. Macrofauna of elodeids in two trophically different lakes I. Relations between elodeids and qualitative and quantitative structure of the fauna associated with them. Ekol. pol. 31.

Krecker, F. H., 1939. A comparative study of the animal population of certain submerged aquatic plants. Ecology 20: $553-562$.

Laupy, M., 1977. Relations among the submerged macrovegetation, the quantity of nannoseston and the pondbottom fauna. Vest. cs. spol. zool. 16: 31-40.

Markosova, R, 1974. Seasonal dynamics of the periphytic macrofauna in carp ponds in South-West Bohemia. Vest. cs. spol. zool. 38: 251-270.

Mason, C. F. \& R. J. Bryant, 1975. Periphyton production and grazing by chironomids in Alderfen Broad, Norfolk. Freshwat. Biol. 5: 271-277.

Meijer, M. L., A. J. P. Raat \& R. W. Doef, 1989. Restoration by manipulation of Lake Bleiswijkse Zoom (The Netherlands): first results. Hydrobiol. Bull. 23: 49-57.

Moore, J. W., 1975. The role of algae in the diet of Asellus aquaticus L. and Gammarus pulex L. J. anim. Ecol. 44: 719-730.

Moss, B., 1980. Ecology of freshwaters. Blackwell Scientific Publications, Oxford, $332 \mathrm{pp}$.

Moss, B., K. Irvine \& J. Stanfield, 1988. Approaches to the restoration of shallow eutrophicated lakes in England. Ver. int. Ver. Limnol. 23: 414-418.

Otto, C. \& B. Svensson, 1981. How do macrophytes growing in or close to water reduce their consumption by aquatic herbivores? Hydrobiologia 78: 107-112.

Ozimek, T., R. D. Gulati \& E. van Donk, 1990. Can macrophytes be useful in biomanipulation of lakes? The Lake Zwemlust example. Hydrobiologia 200/201: 399-407.

Parma, S., 1971. Chaoborus flavicans (Meigen, Diptera, Chaoboridae) an autecological study. Ph.D. Thesis, University of Groningen, $128 \mathrm{pp}$.

Pinkster, S., H. Smit \& N. J. Brandse-De, 1977. The introduction of the Alien Amphipod Gammarus trigrinus Sexton, 1939, in the Netherlands and its composition with indigenous species. Crustaceana Suppl. 4: 91-105.

Rooke, J. B., 1984. The invertebrate fauna of four macrophytes in a lotic system. Freshwat. Biol. 14: 507-513.

Rosine, W. N., 1955. The distribution of invertebrates on submerged aquatic plants surfaces in Muskee Lake. Ecology 36: 377-381.

Slepukhina, T. D., 1986. Limnology of the lakes Kubenskoye, Vozhe and Lacha. Zoobenthos. In S. Hejny, J. M. Raspopov and J. Kvet, J. (eds.), Academia Publishing House of the Czechoslovakian Academy of Sciences, Praha: 53-57.

Strayer, D. \& G. Likens, 1986. An energy budget for the zoobenthos of Mirror Lake, New Hampshire. Ecology, 67: 303-313.

Van Donk, E., R. D. Gulati \& M. P. Grimm, 1989. Food web manipulation in Lake $Z$ wemlust: positive and negative effects during the first two years. Hydrobiol. Bull. 23: 19-34. 